\title{
Fatal case of commercial moisture absorber ingestion
}

\author{
Kwanghyun Cho, Beomsok Seo, Hyunseung Koh, Heebum Yang
}

Department of Emergency Medicine, Nowon Eulji Medical Center, Eulji University, Seoul, Korea (the Republic of)

\section{Correspondence to Dr Heebum Yang, heebeom@gmail.com}

Accepted 12 April 2018
Check for updates

To cite: Cho K, Seo B, Koh $\mathrm{H}$, et al. BMJ Case Rep Published Online First: [please include Day Month Year]. doi:10.1136/bcr-2018 225121

\section{DESCRIPTION}

One of the most commercially available moisture absorbers is a dehydrating agent containing calcium chloride. In humid environments such as basements, kitchens, cabinets and closets, calcium chloride provides effective moisture absorption by becoming highly concentrated calcium chloride brine. Ingestion of calcium chloride can lead to severe hypercalcaemia and can be fatal. In our case, hypercalcaemia developed from intentional ingestion of moisture absorber and the patient eventually died. To our knowledge, fatality from commercial moisture of absorber ingestion has not been reported. A 31-year-old man presented to the emergency department (ED) 20 min after intentionally ingesting $300 \mathrm{~mL}$ of commercial moisture absorber solution. It contained $300 \mathrm{~g}$ of calcium chloride (figure 1). The patient had a history of a pervasive developmental disorder. When the patient first presented to ED, he was alert. The patient's initial symptoms were nausea and vomiting. Gastric lavage was done, and activated charcoal was used. Although initial vital signs were relatively stable, initial ECGs revealed sinus bradycardia (36 bpm), with corrected QT interval of $421 \mathrm{~ms}(<430 \mathrm{~ms})$ which, in subsequent study, increased to $512 \mathrm{~ms}$. The results of the laboratory studies were as follows: serum total calcium $20.7 \mathrm{mg}$ / $\mathrm{dL}(8.2-10.8 \mathrm{mg} / \mathrm{dL})$, ionised calcium $3.82 \mathrm{mmol} / \mathrm{L}$ $(1.13-1.32 \mathrm{mmol} / \mathrm{L})$, blood urea nitrogen $18.9 \mathrm{mg} /$ $\mathrm{dL} \quad(7.8-22.0 \mathrm{mg} / \mathrm{dL})$, creatinine $0.78 \mathrm{mg} / \mathrm{dL} \quad(0.7-$ $1.2 \mathrm{mg} / \mathrm{dL})$, albumin $4.2 \mathrm{~g} / \mathrm{dL}(3.1-5.2 \mathrm{~g} / \mathrm{dL})$, phosphorus $5.3 \mathrm{mg} / \mathrm{dL}(2.5-5.5 \mathrm{mg} / \mathrm{dL})$, creatine kinase $94 \mathrm{IU} / \mathrm{L}(38-174 \mathrm{IU} / \mathrm{L})$, sodium $139 \mathrm{mmol} / \mathrm{L}$, potassium $4.0 \mathrm{mmol} / \mathrm{L}$ and chloride $107 \mathrm{mmol} / \mathrm{L}$. Blood

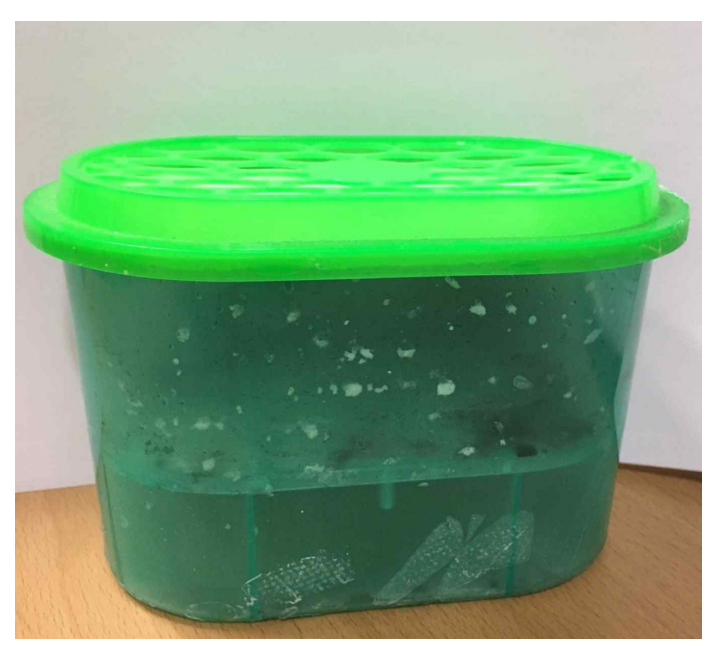

Figure 1 Ingested commercial moisture absorber. analysis results were $\mathrm{pH} 7.37, \mathrm{paCO}_{2} 45 \mathrm{~mm} \mathrm{Hg}$, $\mathrm{paO}_{2} 81 \mathrm{mmHg}$ and bicarbonate $26 \mathrm{mmol} / \mathrm{L}$ on room air. Urinary calcium excretion was not measured. Patient was given adequate normal saline, pamidronate and then furosemide intravenously. The second arterial blood gas analysis was done 1 hour and $40 \mathrm{~min}$ after the patient's arrival. $\mathrm{pH}$ of 7.25 , $\mathrm{PaCO}_{2} 43 \mathrm{~mm} \mathrm{Hg}, \mathrm{PaO}_{2} 123 \mathrm{~mm} \mathrm{Hg}$ and bicarbonate $18.9 \mathrm{mmol} / \mathrm{L}$ were measured. For the treatment of advanced metabolic acidosis, we had to manage it with haemodialysis. At that time, however, there was no continuous renal replacement therapy (CRRT) equipment available at our hospital, so the patient had to be transferred to nearby hospital. CRRT device w as applied immediately after the patient's transfer, but unfortunately symptoms. did not improve. On the fifth day of hospitalisation, the patient eventually died of multiple organ failure. Hypercalcaemia has many causes; more than $90 \%$ of cases result from primary hyperthyroidism or malignancy. ${ }^{1}$ Other causes of hypercalcaemia include chronic lithium therapy, thiazide diuretics, pheochromocytoma, adrenal insufficiency, theophylline toxicity and vitamin $\mathrm{D}$ poisoning, ${ }^{2}$ and there was a fatal case of hypercalcaemia due to calcium channel blocker ingestion. In general, treatment of hypercalcaemia is aimed at lowering serum calcium levels. Despite best efforts, the patient remained in shock with signs of renal failure while on CRRT and eventually hepatic failure ensued. The cause of death was announced as multiple organ failure due to complications of hypercalcaemia by the treating medical team.

Contributors KC, BS and HY performed history and examination, acquired diagnostic data and studies, prepared the manuscript and images and reviewed the literature. HY designed the treatment plan. HK and HY wrote and edited the manuscript and prepared the learning points. HY prepared the final version and approval of the manuscript.

Funding This research received no specific grant from any funding agency in the public, commercial or not-for-profit sectors.

Competing interests None declared.

Patient consent Parental/guardian consent obtained.

Provenance and peer review Not commissioned; externally peer reviewed.

(C) BMJ Publishing Group Ltd (unless otherwise stated in the text of the article) 2018. All rights reserved. No commercial use is permitted unless otherwise expressly granted.

\section{REFERENCES}

1 Minisola S, Pepe J, Piemonte S, et al. The diagnosis and management of hypercalcaemia. BMJ 2015;350:h2723.

2 Marins TA, Galvão TF, Korkes F, et al. Vitamin D intoxication: case report. Einstein 2014;12:242-4. 
Copyright 2018 BMJ Publishing Group. All rights reserved. For permission to reuse any of this content visit http://group.bmj.com/group/rights-licensing/permissions.

BMJ Case Report Fellows may re-use this article for personal use and teaching without any further permission.

Become a Fellow of BMJ Case Reports today and you can:

- Submit as many cases as you like

- Enjoy fast sympathetic peer review and rapid publication of accepted articles

Access all the published articles

- Re-use any of the published material for personal use and teaching without further permission

For information on Institutional Fellowships contact consortiasales@bmjgroup.com

Visit casereports.bmj.com for more articles like this and to become a Fellow 